Key words: consolidation, solidarity, group behavior, integration, identification, identity, well-being, social capital.

УДК 159.9 - 796.03:[005.32:316.614]

DOI: https://doi.org/10.35619/prap_rv.vi12.61

\section{3. Ю. КРИЖАНОВСЬКА, С. МІРЧЕНКО}

\title{
МОТИВАЦИЙНИЙ КОМПОНЕНТ САМОРЕАЛІЗАЦІЇ В СПОРТИВНІЙ ДІЯЛЬНОСТІ
}

У статті здійснено аналіз мотивачійної детермінаиії самореалізаиії особистості в спорті. Окреслено специфіку спортивної діяльності. Ї̈ визначено, як універсальну сферу для повноцінної й органічної самореалізаиії особистості. Встановлено, що розвиток наукового розуміння феномену самореалізації належить представникам екзистенційно-гуманістичного напряму в філософії. Самореалізація розглядається як спосіб максимального самовиповнення себе у житті. Встановлено значущеість мотивачійних компонент особистості в процесі самореалізациї в спорті.

Емпірично доведено, щяо для більшості молодих спортсменів спорт $\epsilon$ сферою для самореалізації. Їхнє розуміння поняття “самореалізаиія” узгоджується з класичним його визначенням. 3 'ясовано, щз мотивація у різних груп спортсменів різниться за змістом. Мотиваційна детермінація самореалізованих в спорті волейболістів відображає зміст та характеристики спортивної діяльності.

Ключові слова: спорт, мотивачія, самореалізачія, спортивна діяльність, волейбол.

В статье осуществлен анализ мотиващионной детерминации самореализации личности в спорте. Определено специфику спортивной деятельности. Она определена, как универсальная сфера для полноценной и органической самореализации личности. Установлено, что развитие научного понимания феномена самореализачии принадлежит представителям экзистенциальногуманистического направления в философии. Самореализащия рассматривается как способ максимального самовиповнення себя в жизни. Установлено значимость мотивационных компонент личности в процессе самореализачии в спорте.

Эмпирически доказано, что для большинства молодых спортсменов спорт является сферой для самореализации. Их понимание понятия "самореализация" согласуется с классическим его определением. Выяснено, что мотивачия у различных групп спортсменов отличается по содержанию. Мотивационная детерминация самореализированных в спорте волейболистов отражает содержание и характеристики спортивной деятельности.

Ключевые слова: спорт, мотивачия, самореализация, спортивная деятельность, волейбол.

Постановка проблеми. Звертання до емпіричного аналізу феномену самореалізації особистості в спорті в час сьогодення має сенс і він змістотворчий з огляду на ті соціальні зміни, які робляться дійсністю у нових демократичних умовах. Здоровий спосіб життя активно входить в систему життєвоважливих цінностей українців та займає чільне місце в ієрархії ії базових потреб. Життя сучасної людини переконливо доводить, що заняття спортом сьогодні $є$ не лише сферою активності спортсменів-професіоналів, а й невід'ємною ланкою життя кожної психологічно зрілої особистості.

Спортивна діяльність є однією з тих сфер активності людини, де вона здатна проявити власну досконалість, використовуючи фізичні можливості для досягнення високих результатів. Спорт $€$ органічним самій природі людини, що сприяє реалізації в ньому іiі вроджених можливостей та потенцій. Окрім того, спорт відзначається чіткими критеріями оцінки його результатів, вимагає високої активності та чіткого цілепокладання від людини. Він потребує не лише достатнього рівня фізичної, але й психічної готовності особистості, високого самоконтролю та саморегуляції, сформованої волі та резистентності для подолання не лише супротиву сильного суперника, а й власних слабкостей. Спортивна діяльність - універсальна в своїй суті, адже вона гармонійно інтегрує не лише фізичну, а й інтелектуальну, мотиваційну, соціальну сфери особистості, що є гідним підгрунтям для іiї цілісного розвитку та самореалізації. Унікальність спортивної діяльності людини визначаться й тим, що вона не базується на розвитку лише рухових, фізичних здібностей людини, а виконує інші функції в ії онтогенетичному функціонуванні. 3-поміж функціональних аспектів спорту можемо виділити прикладний, який виявляється в підготовці людини до інших видів суспільної діяльності; естетичний, як насолоду від майстерно виконаних рухів та вправ; соціальний, як засіб вербальної та невербальної комунікації та взаємодії, творчий.

Випуск 12, 2019. Збірник наукових праць РДГУ 
Спортивні результати високого рівня є престижними, а їх носії-соціально визнаними та успішними. Відтак, спорт інтегрує в собі поліфункціональні можливості для комплексного гуманістичного впливу на людину. Він дає змогу свідомо, цілеспрямовано та ефективно впливати на різноманітні фізичні, психічні та духовні якості та здібності людини й сприяти їх максимальному розвитку та самореалізації.

3 огляду на сказане вище проблема самореалізації особистості в спорті сприймається актуальною та практично значущою.

Аналіз останніх досліджень і публікацій. Прообрази деяких ідей, котрі лежать в основі проблеми самоактуалізації людини, можна зустріти вже в античній філософії і релігійних вченнях Давнього світу (Л. Альберті, Ф. Петрарка). Науковий підхід до проблеми самоактуалізації починається із спроб філософів другої половини XIX ст. поставити в центр філософського вчення життя людини (А. Бергсон, В. Виндельбанд, В. Дільтей, Е. Шпрангер, С. Франк та ін.). Багатогранність феномену самореалізації особистості почала всебічно вивчатися філософією 3 розвитком екзистенційно-гуманістичного напряму (А. Маслоу, Р. Мей, Г. Олпорт, К. Роджерс, В. Франкл, Е. Фром та ін.), що знайшло своє продовження в працях інших науковців-психологів (К. Абульханова-Славська, Л. Анциферова, Б. Богоявленська, Т. А. Колтунович, Л. Мова, Т. Титаренко та ін.) [5].

Методологічним для нашого дослідження є положення О. М. Леонтьєва, про те, що сутність будь-якої діяльності можна визначити як єдність цілі, мотивів, дій (операцій), результату, причому ії системотворчою характеристикою є ціль [6]. Відповідно до цього положення, успішність та ефективність спортивної діяльності визначається не лише розвитком фізичної, емоційної, інтелектуальної сфер особистості, а, перш за все, характером іiї мотиваційної сфери - змістом мотивів, їх спрямованістю та ступенем активності. Відтак, на думку В. О. Бодрова [1], мотивація може компенсувати багато недоліків у рівні розвитку ряду професійно важливих якостей і в організації спортивної діяльності, зокрема, але слабку мотивацію практично неможливо компенсувати. Актуальним є з'ясування того, які саме мотиви є базовими у спортивній діяльності спортсмена, що забезпечило б i високу ефективність його активності, i розвиток його професіоналізму, і суб'єктивну задоволеність роботою і прагнення до самореалізації в ній.

Формулювання цілей статті: здійснене теоретико-емпіричне дослідження має на меті виокремити мотиваційні характеристики самореалізованих в спорті особистостей.

Виклад основного матеріалу дослідження. Теоретичне обгрунтування проблеми дало змогу розробити програму фіксації, аналізу й оцінки мотиваційних характеристик самореалізованих в спорті особистостей. Для проведення дослідження вибрано навчально-тренувальний процес (НТП) групи початкової підготовки, яка перебуває на останньому році навчання. Контингентом дослідження виступили юні спортсмени-волейболісти в кількості 38 осіб, які тренуються в комплексній ДЮСШ № 1 м. Луцька.

Методичне забезпечення дослідження було реалізоване такими методиками: методика діагностики спрямованості особистості Смекала-Кучера, методика діагностики особистісних $i$ групових базових потреб А. Маслоу та методика діагностики мотиваційної структури B.E. Мільмана для вивчення мотиваційних детермінант спортсменів та авторська анкетаопитувальник для вивчення особливостей самореалізації наших досліджуваних.

Перейдемо до аналізу основних результатів емпіричного дослідження, отриманих за допомогою авторської анкети-опитувальника. Відтак, високий відсоток ствердної відповіді (98\% опитаних) ми отримали на запитання: “Чи вважаєте Ви себе самореалізованою особистістю?”. На запитання: “Як на Вашу думку, що означає бути самореалізованою особистістю?” наші досліджуваніспортсмени давали здебільшого такі відповіді: “... бути максимально виповненим в житті”, “... бути задоволеним від того, що ти робиш”, “... задіяти всі свої ресурси” та подібні. Ці відповіді свідчать про те, що юні спортсмени розуміють смисл поняття “самореалізація” та здатні оцінити власну реалізованість. На запитання: "Яка зі сфер Вашого життя сприяє найбільш повній особистісній самореалізації?", 98 \% досліджуваних дали відповідь - “Спорт”. На запитання: “Чи плануєте Ви своє майбутнє життя пов’язати зі спортом?”, наші досліджувані відповіли - “Так” (96 \% ).

Аналіз цих відповідей дає нам змогу стверджувати, що юні спортсмени є самореалізованими в спорті особистостями та відповідають вимогам нашого дослідження. Перейдемо до аналізу мотиваційних детермінант самореалізації юних спортсменів.

За допомогою методики діагностики спрямованості особистості Смекала-Кучера досліджувані поділилися на три підгрупи на основі їх домінуючої спрямованості. Результати дослідження за цією методикою представляємо в таблиці 1. 


\section{Результати дослідження спортсменів-волейболістів за методикою Смекала-Кучера}

\begin{tabular}{|l|c|c|c|}
\hline \multicolumn{1}{|c|}{ Назва шкали } & $\begin{array}{c}\text { Спрямованість на } \\
\text { себе }\end{array}$ & $\begin{array}{c}\text { Спрямованість на } \\
\text { задачу }\end{array}$ & $\begin{array}{c}\text { Спрямованість на } \\
\text { взаємодію }\end{array}$ \\
\hline $\begin{array}{l}\text { Кількість } \\
\text { досліджуваних (\%) }\end{array}$ & 12 & 58 & 30 \\
\hline
\end{tabular}

Як засвідчують результати дослідження, подані в таблиці 1, найменш чисельною (12\% досліджуваних) є група, яка продемонструвала спрямованість на себе, як домінантну. Її психологічні показники свідчать про перевагу мотивів власного благополуччя, прагнення до особистої першості, престижу. найчисельнішою група, яка проявила домінантну спрямованість на задачу є і становить $58 \%$ від загальної кількості вибірки. Це спрямування відображає переважання мотивів, зумовлених змістом самої діяльності, захопленням іiі процесом, оволодіння новими вміннями та навичками. Група, яка проявила домінантну спрямованість на взаємодію - середня за чисельність у вибірці, проте має значне відсоткове співвідношення - 30\% досліджуваних. Це спрямування має місце тоді, коли вчинки людини визначаються потребою в спілкуванні, комунікації, прагненням підтримувати гарні взаємини з оточуючими людьми, налагодженні нових взаємин.

В подальшому аналіз мотиваційних показників здійснювався нами по виділеним, на основі домінуючої спрямованості, підгрупам. За результатами методики діагностики мотиваційної структури особистості В. Е. Мільмана було констатовано відмінності у мотиваційних структурах трьох виділених за змістом спрямованості груп. Так, для юних спортсменів-волейболістів 3 домінуючою спрямованістю на задачу характерний прогресивний мотиваційний профіль, який характеризується помітним перевищенням рівня розвивальних мотивів (до яких відносяться мотиви загальної і творчої активності, а також суспільної корисності) над рівнем мотивів споживання (підтримання життєзабезпечення, прагнення комфорту та соціального статусу). Досліджуваним 3 переважаючою спрямованістю на взаємодію також характерний мотиваційний профіль, наближений за результатами до спортсменів-волейболістів першої підгрупи. А саме, високими за значеннями були показники шкали “спілкування" (Хсер= 41,2 бали), “загальна активність” (Хсер=29,9 бали), “творча активність” (Хсер=27,9 бали), “суспільна корисність” (Хсер=31,7 бали). Спортсменам з домінуючою спрямованістю на себе, навпаки, більшою мірою властивий регресивний мотиваиійний профіль, що характеризується перевагою загального рівня мотивів підтримання над мотивами розвитку.

За допомогою "Методики діагностики особистісних $і$ групових базових потреб” А. Маслоу було виявлено, що у спортсменів-волейболістів з орієнтацією на себе, домінуючі позиції займають матеріальні та соціальні потреби, що може слугувати підставою для висновку про те, що для цих молодих людей пріорітетним є задоволення власних прагматичних інтересів. У досліджуваних 3 домінуючою спрямованістю на задачу питому вагу набули потреби у самовираженні та самореалізації, що узгоджується з нашим припущенням про те, що спорт $є$ для них визначеною сферою їх самореалізації та самовиповнення. Для юних спортсменів зі спрямованістю на взаємодію, основними визначились соціальні потреби та потреби самовираження.

Висновки 3 даного дослідження і перспективи подальших розвідок. Отож, здійснене нами теоретико-емпіричне дослідження дало змогу констатувати, що юні спорстмени-волейболісти $\epsilon$ самореалізованими в спорті особистостями. Їхнє розуміння поняття “самореалізація" узгоджується 3 класичним його визначенням та $\epsilon$ підставою для правильного визначення їх власною самореалізованості в спорті. Вивчення мотиваційних детермінант процесу самореалізації юних волейболістів в спортивній діяльності з'ясувало, що домінуючою мотиваційною спрямованістю $\epsilon$ спрямованість на задачу та на взаємодію. Для цих юних спортсменів більшою мірою характерні потреби, які узгоджуються 3 універсальними життєво-духовними цінностями. Це потреби у самовираженні, які зосереджені у прагненні якомога повніше виявити, розвинути та реалізувати свої можливості й здібності в волейболі, бути професійним спортсменом. У той час, підгрупа спортсменів 3 домінуючою спрямованістю на себе - нечисельна. Для ії контингенту проблема розвитку особистості, реалізації потреби в самоактуалізації знаходиться на нижчих позиціях, а ніж задоволення власних утилітарно-прагматичних потреб.

Ясна річ, що здійснене теоретико-емпіричне дослідження не вичерпує всіх питань мотиваційної наповненості такого непростого процесу самореалізації і може бути продовжене в подальших наукових пошуках.

Випуск 12, 2019. Збірник наукових праць РДГУ 


\section{Список використаних джерел}

1. Бодров В. А. Психология профессиональной пригодности : учеб. пособ. для вузов / В. А. Бодров. - М. : ПЕРСЭ, 2001. - 511 с.

2. Крижановська 3. Ю. Психологічні відмінності в самореалізації підлітків міста та села / 3. Ю. Крижановська, Т. В. Новсад // Психологія: реальність і перспективи : зб. наук. пр. Рівнен. держ. гуманіт. ун-ту. - Рівне : РДГУ, 2018. - Вип. 10. - С. 90-94.

3. Крижановська 3. Ю. Потребово-мотиваційні особливості прояву професійної спрямованості особистості педагога / 3. Ю. Крижановська, А. В. Мітлош // Особистість і суспільство: методологія та практика сучасної психології : матеріали I Міжнар. наук.-практ. інтернет-конф., (13 трав. 2014 р.) / за заг. ред. : Л. В. Засєкіної, А. В. Кульчицької. - Луцьк : ВежаДрук, 2014. - С. 51-54.

4. Крижановська 3. Ю. Самореалізація особистості після виходу на пенсію, як спосіб іiі самовиповнення / 3. Ю. Крижановська, О. Сичак // Психологія: реальність і перспективи : зб. наук. пр. Рівнен. держ. гуманіт. ун-ту. - Рівне : РДГУ, 2016. - Вип. 7. - С. 106-110.

5. Крижановська 3. Ю. Мотиваційні чинники професійної самореалізації фахівців дошкільних закладів : дис. ... канд. психол. наук : 19.00.07 / З. Ю. Крижановська ; Волин. нац. ун-т ім. Лесі Українки. - Луцьк, 2011. - 215 с.

6. Леонтьев А. Н. Деятельность, сознание, личность / А. Н. Леонтьев.- М. : Смысл, Академия, 2005. - 352 с.

\section{References}

1. Bodrov V. A. Psychologija proffesionalnoj prigodnosti : ucheb. posob. dlja vuzov. - M. : PERSE, 2001. $-511 \mathrm{~s}$.

2. Kryzhanovska Z. Ju. Psychologichni widminnosti w samorealizazhiji pidlitkiw mista i sela / Z. Ju. Kryzhanovska, T. V. Novosad // Psychologija: realnist i perspektuwu : zb. nayk. pr. Riwnen. derzh. hymanit. un-tu. - Riwne : RDHU, 2018. - Wyp. 10. - S. 90-94.

3. Kryzhanovska Z. Ju. Potrebowo-motywazhijni osobluwosti projawu profesijnoji sprjamowanosti osobustosti pedaho // Z. Ju. Kryzhanovska, A. W. Mitlosch // Osobustist i syspilstwo: metodologija ta praktuka sychasnoji Psychologii : materialu I Mizhnar. nauk.-prakt. internet-konf., (13 traw. 2014 r.) / za zah. red. : L. W. Zasjekinoji, A. W. Kylchuzhkoji. - Luzk : Wezha-Druk, 2014. - S. 51-54.

4. Kryzhanovska Z. Ju. Samorealizazhija osobustosti pislja wuchodu na pensiju, jak sposib jiji samowupownennja / Z. Ju. Kryzhanovska, O. Suchak // Psychologija: realnist i perspektuwu : zb. nayk. pr. Riwnen. derzh. hymanit. un-tu. - Riwne : RDHU, 2016. - Wyp. 7. - S. 106-110.

5. Kryzhanovska Z. Ju. Motuwazhijni chunnuku profesijnoji samorealizazhiji fachiwzhiw doschkilnuch zakladiw : dus. ... kand. psuchol. nauk : 19.00.07 / Z. Ju. Kryzhanovska ; Wolun. nazh. un-t im. Lesi Ukrajinku. - Luzk, 2011. - 215 s.

6. Leontjev A. N. Dejatelnost, soznanie, lichnost / A. N. Leontjev. - M. : Smusl, Akademija, 2005. $352 \mathrm{~s}$.

\section{Z. Kryzhanovska, S. Mirchenko MOTIVATIONAL COMPONENT OF SELF-REALIZATION IN SPORTS ACTIVITIES}

The article analyzes the motivational determination of the individual self-realization in sports. It defines the specifics of sports activities. They are determined as those that contribute to the complex development of personality. It is a universal sphere for the full and organic self-realization of the individual.

It has been established that the scientific understanding development of the self-realization phenomenon belongs to representatives of the existential-humanistic direction in philosophy. Self-realization is considered as a way of maximal self-perception of a person in life. The article analyzes the psychological structure of activity. The importance of the motivational component of the personality to achieve success in sports has been substantiated.

An empirical study has been conducted over young volleyball players. To achieve the objectives of the study, four methods have been used: a questionnaire and test questionnaires. The results show that for most young athletes, sport is a sphere for self-realization. Their understanding of the concept of "selfrealization" is consistent with its classical definition.

It has been found that the motivation of different groups of athletes differs in content. A group of volleyball players with a dominant motivational focus on the task and on the interaction has been detected. They are more characterized by needs that are consistent with the universal vital spiritual values. These are the needs for self-expression, which are focused on striving to realize their abilities and volleyball skills as 
fully as possible. At that time, the subgroup of athletes with a dominant focus on themselves has been classified as not numerous. For its contingent, the problem of development is on the lower positions, rather than the satisfaction of its own utilitarian-pragmatic needs.

Thereby, the motivational determination of self-realized volleyball players in sports reflects the content and characteristics of sports activities.

Key words: sport, motivation, self-realization, sports activity, volleyball.

\section{УДК 373.3:159.922.74}

Л. М. КУЛАКОВА, Р. С. КУЛАКОВ

DOI: https://doi.org/10.35619/prap_rv.vi12.62

\section{ГІДНІСТЬ ТА МОРАЛЬ: ФІЛОСОФСЬКО-ПСИХОЛОГІЧНИЙ ЗМІСТ}

Стаття присвячена вивченню змісту понять «гідність», «почуття власної гідності», «моральність», «мораль»як філософсько-етичних категорій. Авторами досліджується зміна поглядів на проблему гідності людини та ї моральності у історичному аспекті. Зокрема, здійснено аналіз поглядів на зазначену проблему представниками античності, римського стоӥцизму, середньовічної схоластики, епохи Відродження, Нового часу, епохи Просвітництва, філософами-ідеалістами ХVIIIXIX cm., неокласичними філософами кіния XIX - початку XX cm. та сучасними філософами та психологами. У статті аналізуються основні критерії та чинники гідності людини. Визначено основні напрями осмислення проблеми моральності та гідності людини у психології та філософії.

Ключові слова: гідність, почуття власної гідності, моральність, мораль, честь, моральні почуття, самоповага, самооиінка, самосвідомість, самопізнання.

Статья посвящена изучению содержания понятий «достоинство», «чувство собственного достоинства», «нравственность» как философско-этических категорий. Авторами исследуется изменение взглядов на проблему достоинства человека и его нравственности в историческом аспекте. В частности, осуществлен анализ взглядов на указанную проблему представителями античности, римского стоицизма, средневековой схоластики, эпохи Возрождения, Нового времени, эпохи Просвещения, філософами-идеалистами XVIII-XIX ст., неокласическими філософами кониа XIX - начала XX ст.. и современными философами и психологами. В статье анализируются основные критерии и факторы достоинства человека. Определены основные направления осмысления проблемы нравственности и достоинства человека в психологии и философии.

Ключевые слова: достоинство, чувство собственного достоинства, нравственность, честь, нравственные чувства, самоуважение, самооценка, самосознание, самопознание.

Постановка проблеми. Неоднозначність розуміння проблеми гідності людини різними філософськими школами, труднощі емпіричного вирішення особистістю проблем екзистенціального самовизначення (пошуку відповідей на запитання про природу й цінності людини), а отже, й розв'язання практичних завдань моральності - ціннісного ставлення до іншої людини, обумовлюють важливість окресленої проблематики саме в теперішній історичний момент, коли відбуваються радикальні зміни світоглядних і ціннісних основ суспільства.

Аналіз останніх досліджень і публікацій. На сучасному етапі філософські та етичні аспекти людської гідності висвітлюються у працях Р. Апресяна, Г. Бандзеладзе, О. Дробницького, П. Кравченко, В. Лозового та педагогів Н. Ємузової, Ф. Кадол, В. Сухомлинського, Н. Третьяк, С. Удовицької та ін.

У психологічній науці природа гідності людини висвітлюється через: самоставлення (I. Бех, О. Колишко, К. Роджерс, С. Рубінштейн, Н. Сарджвеладзе, I. Чеснокова та ін.); інтегровану самооцінку (А. Бандура, М. Вагнер, У.Джеймс та ін.); самоцінність й самоповагу (Ч. Кулі, В. Маралов, В. Савельєв, В. Сафін та ін.); моральну самосвідомість (М. Боришевський, Б. Братусь, І. Булах, Р.Павелків, В. Столін та ін.).

У світовій психологічній науці різні аспекти почуття власної гідності розглядали Ч. Кулі (через структуру «дзеркального Я»), Г. Оллпорт (специфіка зрілості особистості), А. Маслоу (в рамках потреб особистості), К. Роджерс (через самоприйняття особистості), Дж. Хетті (самоставлення особистості), Дж. Каган (висвітлюе гідність особистості), М. Якобі (самоцінність особистості), Т. Шибутані (визначає критерії почуття власної гідності).

Вітчизняні вчені (I. Бех, I. Булах, М. Боришевський, О. Колесник, В. Рибалка та ін.) у своїх дослідженнях звертаються до людської гідності, особливостей розвитку почуття власної гідності в онтогенезі особистості як структурної одиниці самоставлення й підгрунтя поваги до себе; 